\title{
橋脚井筒の弾性動摇振動におよぼすセン断効果
}

\author{
正員 後藤 盆 男*

\section{ON THE EFFECT OF SHEARING FORCE ON THE ELASTIC AND ROCKING VIBRATION OF BRIDGE PIERS AND WELL CONSTRUCTIONS} \\ (Trans. of JSCE, No. 29, Dec. 1955) \\ Hisao Gotō, C.E. Member
}

Synopsis The vibration characteristics of the bridge piers and well constructions are, as the author proposed hitherto, explained by the elastic and rocking vibration phenomena. In this respect, a shearing effect on the above-mentioned phenomena was investigated theoretically as the following three types: (1) bending and sbearing vibration, (2) bending vibration, (3) shearing vibration. Applying these solutions to the actual bridge piers and well constructions, the numerical computation was carried out carefully. The result obtained was that the shearing effect is negligible small to the vibration characteristics of bridge piers and well constructions in spite of their dumpy forms.

要 旨 橋脚井筒は基礎地盤の影響をうけて，弾性動摇振動を行うことを著者はすでに確認したが， 本研究は引続いてこの振動に及ぼすセン断効果について詳細な考究を進めたすのである。この場合 弾性動摇振動を 1) 曲げセン断振動，2）曲げ振動，3）セン断振動の三者と乙て理論的な解析を行 い，契在橋脚井筒を例にとつて詳細な数值計算を実施した。この結果道路橋の橋軸值角方向のよ うに，長さそ対して横断寸法がかなり大さいいわゆる太くかつ短かい寸法の橋脚井筒で, 弾性動摇 振動のいらじるしい特性としてセン断効果は非常に小さく，事実上これを無視してもるいるいう注 目すべき成果を収めることができた。

\section{1. 緒言}

著者はここ数年来橋脚地艋の基碟係数值 $K\left(x_{1}\right)$ を採用した橋脚井筒の振動性状を研究してきたが，いずれの 場合でも橋脚井筒は太くかつ短かい形状をるつているともかかわらず，七ン断の影響は比較的小さいものとして 無視し，振動性状をるつぱら曲げ振動的に取扱つてきだ”。かて道路橋の下部構造として建設されている井筒基

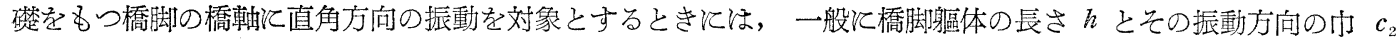
との比 $c_{2} / h$ 及び井筒に和けるこの比 $c_{1} / d$ (図一-1(1)) がいずれる1の前後のととが多い（たと光ば図-4(1))。 こうした場合にも果してセン断の影響は小さいとして無視してもよいであろうかという当然の疑念が物こる。本 研究では特とこの点を直接解明しょうとするるのである。

セン断及び回転慣性を考慮したハリの振動関する基礎方程式はよく知られていると招り，Timoshenko とよ

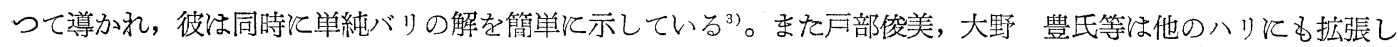
ているが，両氏等の境界条件のとり方には少敢からざる疑点がある ${ }^{4)}$ 。そののち酒井忠明教授は中空内筒片持バリ のセン断曲げ振動点を, 石崎潑雄助教授は片持バリのセン断曲げ振動及び高首ビル（地下，地上の 2 区間）のセン 断振動 ${ }^{6}$ といずれも戸部，大野氏等と異なるセン断角を重視した合理的な境界条件を用いて解明している。しかし 酒井教授が地表面で完全固定と考皇た単なる片持バリに言及している点，石崎助教授が 2 区間振動ではセン断の みを対象とし，乙かも基礎方程式中で地盤の基礎反力による項を慣性項と異符号と考学た点》等はいずれる本文に 柱そのます適用することができない。とこで本文では正しいと思われる酒井教授，石崎助教授の境界条件の表示 法を引用して，橋脚井筒の 2 区間（地上部及び地中部）の曲げセン断の各動摇振動を解明したわけである。

著者はすでそ弾性動摇振動の意義を独自の立場から強調したが8 ${ }^{8}$ ，本研究の結果さらとその本貿を明確とするこ とができた。実際に理論を進めると当つては弾性動摇振動として最低次の振動数のみをとり，かつセン断効果を 究明するという命題からそれないと思われる範囲内で，次の仮定ないし簡易的な取扱い法を採ることにした。1) 振動はすべて均一断面のハリ理論飞従 5，2）回転慣性の影響は一応考虑しない，3）基礎係数值は根入深さ方向 飞一定と仮定して $K\left(x_{1}\right)=K_{0}$ と㧈く，4）井筒底面の上向反力を無視する，5）数值計算飞当つては上部構造に よる載荷重量 $W$ を除外する。

\section{2. 曲げセン断振動に関する基礎方程式}

図一1（1），(2）の根入区間 $\mathrm{AB}$ (井筒：添字 1 を付す）を Timoshenko と同様に，曲げ : $b$ ， セン断： $s$ ，回転

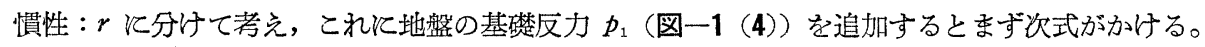

* 京都大学助教授, 工学部土木工学教室 


$$
\begin{aligned}
& y_{1}=y_{1 b}+y_{1 s}+y_{1 r}, \quad p_{1}=b_{1} K\left(x_{1}\right) y_{1}, \\
& \varphi_{1}=\frac{\partial y_{1}}{\partial x_{1}}=\varphi_{1 b}+\varphi_{1 s}+\varphi_{1 r}, \quad M_{1}=-E_{1} I_{1} \frac{\partial}{\partial x_{1}}\left(\varphi_{1 b}+\varphi_{1 r}\right), \\
& S_{1}=k_{1}^{\prime} a_{1} G_{1} \varphi_{1 s}, \quad \text { かつ } S_{1}=\frac{\partial M_{1}}{\partial x_{1}} .
\end{aligned}
$$

ここに $y_{1}, \varphi_{1}, M_{1}, S_{1}$ : 変位, 傾斜, 曲げモーメ ント, セン断力, $E_{1} I_{1}$ : 曲げ岡性, $G_{1}$ : セン断弾性 係数, $k_{1}{ }^{\prime}$ : セン断力に関する断面形状係数, $a_{1}$ : 断 面積, $b_{1}$ : 奥行门。

図一-1（4）飞着目すると回転及び直線運動として，

$$
\left.\begin{array}{l}
S_{1} d x_{1}-\frac{\partial M_{1}}{\partial x_{1}} d x_{1}=\frac{I_{1} w_{1}}{g} \frac{\partial^{2}}{\partial t^{2}}\left(\varphi_{1 b}+\varphi_{1 r}\right) d x_{1}, \\
\frac{\partial S_{1}}{\partial x_{1}} d x_{1}-p_{1} d x_{1}=\frac{w_{1} a_{1}}{g} \frac{\partial^{2} y_{1}}{\partial t^{2}} \partial x_{1}
\end{array}\right\}
$$

がえられる。いうまでるなく $w_{1}$ : 単位体積の重量,

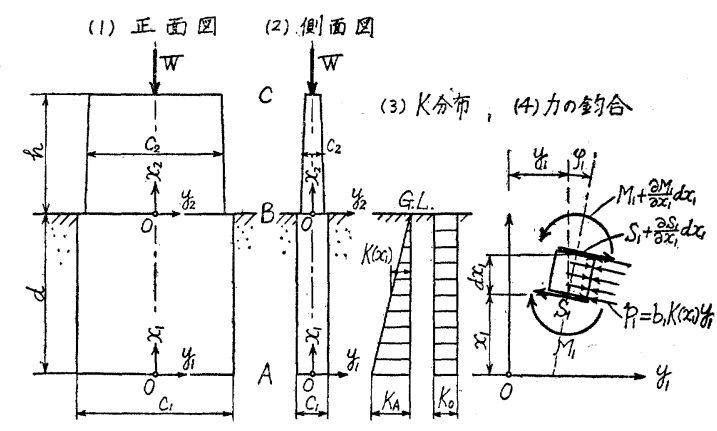
$g$ : 重力の加速度。式 (2) 记式 (1) を代入して式 (3) をうる。

$$
\left.\begin{array}{l}
E_{1} I_{1} \frac{\partial^{2}}{\partial x_{1}{ }^{2}}\left(\varphi_{1 b}+\varphi_{1} r\right)+k_{1}{ }^{\prime} a_{1} G_{1}\left(\varphi_{1}-\varphi_{1 b}-\varphi_{1 r}\right)=\frac{I_{1} w_{1}}{g} \frac{\partial^{2}}{\partial t^{2}}\left(\varphi_{1 b}+\varphi_{1 r}\right), \\
k_{1}{ }^{\prime} a_{1} G_{1} \frac{\partial}{\partial x_{1}}\left(\varphi_{1}-\varphi_{1 b}-\varphi_{1 r}\right)-b_{1} K\left(x_{1}\right) y_{1}=\frac{w_{1} a_{1}}{g} \frac{\partial^{2} y_{1}}{\partial t^{2}}
\end{array}\right\}
$$

式 (3) から $\varphi_{1 b}+\varphi_{1 r}=\varphi^{\prime}$ を消去するため, 式 (3) ${ }_{2}$ から $\partial \varphi_{1}{ }^{\prime} / \partial x_{1}$ 索繰り出し，乙れから $\partial^{3} \varphi_{1}{ }^{\prime} / \partial x_{1}{ }^{3}$ を作り， これらを $\partial / \partial x_{1} ・[$ 式 (3) $]$ 亿代入すると回転慣性を考慮した場合の次の基礎方程式をうる。

$$
\begin{aligned}
E_{1} & I_{1} \frac{\partial^{4} y_{1}}{\partial x_{1}{ }^{4}}-\frac{b_{1} K\left(x_{1}\right) E_{1} I_{1}}{k_{1}{ }^{\prime} a_{1} G_{1}} \frac{\partial^{2} y_{1}}{\partial x_{1}{ }^{2}}-\frac{I_{1} w_{1}}{g}\left(1+\frac{E_{1}}{k_{1}{ }^{\prime} G_{1}}\right) \frac{\partial^{4} y_{1}}{\partial x_{1}{ }^{2} \partial t^{2}} \\
& +b_{1} K\left(x_{1}\right) y_{1}+\frac{w_{1} a_{1}}{g}\left(1+\frac{I_{1} b_{1} K\left(x_{1}\right)}{k_{1}{ }^{\prime} a_{1}{ }^{2} G_{1}}\right) \frac{\partial^{2} y_{1}}{\partial t_{2}}+\frac{I_{1} w_{1}{ }^{2}}{k_{1}{ }^{\prime} G_{1} g^{2}} \frac{\partial^{4} y_{1}}{\partial t^{4}}=0
\end{aligned}
$$

地上部 $\mathrm{BC}$ 飞ついては式 (4)で $K\left(x_{1}\right)=0$ と扔き，かつ添字 1 をすべて添字 2 亿改めると, 当然 Timoshenko と同一の結果として式 (5) をらる。

$$
E_{2} I_{2} \frac{\partial^{4} y_{2}}{\partial x_{2}{ }^{4}}-\frac{I_{2} w_{2}}{g}\left(1+\frac{E_{2}}{k_{2}{ }^{\prime} G_{2}}\right) \frac{\partial^{4} y_{2}}{\partial x_{2}{ }^{2} \partial t^{2}}+\frac{w_{2} a_{2}}{g} \frac{\partial_{2} y_{2}}{\partial t^{2}}+\frac{I w_{2}{ }^{2}}{k_{2}{ }^{\prime} G_{2} g^{2}} \frac{\partial^{4} y_{2}}{\partial t^{4}}=0 \ldots
$$

式 (4)，(5) を連立に解くと，図一1 亿対する自由振動の解が求まる。ここで緒言に述べたようと回転慣性を無 視して式 (1)，(2)，(3) で $\varphi_{1 r}=0$ と招き，かつ $K\left(x_{1}\right)=K_{0}$ と和くと曲げセン断振動関する基礎方程式 (6) 及び (7)をうる。

$$
\begin{aligned}
& E_{1} I_{1} \frac{\partial^{4} y_{1}}{\partial x_{1}{ }^{4}}-\frac{E_{1} I_{1} b_{1} K_{0}}{k_{1}{ }^{\prime} a_{1} G_{1}} \frac{\partial^{2} y_{1}}{\partial x_{1}{ }^{2}}-\frac{E_{1} I_{1} w_{1}}{k_{1}{ }^{\prime} G_{1} g} \frac{\partial^{4} y_{1}}{\partial x_{1}{ }^{2} \partial t^{2}}+b_{1} K_{0} y_{1}+\frac{w_{1} a_{1}}{g} \frac{\partial^{2} y_{1}}{\partial t^{2}}=0 \\
& E_{2} I_{2} \frac{\partial^{4} y_{2}}{\partial x_{2}{ }^{4}}-\frac{E_{2} I_{2} w_{2}}{k_{2}{ }^{\prime} G_{2} g} \frac{\partial^{4} y_{2}}{\partial x_{2}{ }^{2} \partial t^{2}}+\frac{w_{2} a_{2}}{g} \frac{\partial^{2} y_{2}}{\partial t^{2}}=0
\end{aligned}
$$

\section{3. 振動数方程式及び正規函数}

（1）基礎方程式の一般解 図一1で $\mathrm{AB}$ と BC とが一体となつて振動すると考えると, 両区間共通の振動数 $n$ と位相角 $\phi$ とを用いて式 (8) がかける。

$$
y_{1}=u_{1} \cos (n t+\phi), \quad y_{2}=u_{2} \cos (n t+\phi)
$$

ここに $u_{1}, u_{2}$ はいうまでもなく $\mathrm{AB}, \mathrm{BC}$ そ対する振動形状を与える正規函数である。式 (8) を式 (6)，(7) 飞代入乙て時間函数 $\cos (n t+\phi)$ を消去すると,

$$
\begin{aligned}
& \frac{d^{4} u_{1}}{d x_{1}{ }^{4}}-\frac{1}{k_{1}{ }^{\prime} a_{1} G_{1}}\left(b_{1} K_{0}-\frac{w_{1} a_{1} n^{2}}{g}\right) \frac{d^{2} u_{1}}{d x_{1}{ }^{2}}+\frac{1}{E_{1} I_{1}}\left(b_{1} K_{0}-\frac{w_{1} a_{1} n^{2}}{g}\right) u_{1}=0 \\
& \frac{d^{4} u_{2}}{d x_{2}{ }^{4}}+\frac{w_{2} n^{2}}{k_{2}{ }^{\prime} G_{2} g} \frac{d^{2} u_{2}}{d x_{2}{ }^{2}}-\frac{w_{2} a_{2} n^{2}}{E_{2} I_{2} g} u_{2}=0
\end{aligned}
$$

式 (9) を解〈のに $\left.\left(b_{1} K_{0}-w_{1} a_{1} n^{2} / g\right)\right\rangle,=,\langle 0$ が問題となる。ところが本研究で対象としている振動数 $n$ は その最小值 $n_{\min }$ である。簡単のため $n_{\min }=n_{\mathrm{I}}$ とかくと, 著者の前論文から $\left(b_{1} K_{0}-w_{1} a_{1} n_{\mathrm{I}}^{2} / g\right)>0$ であること 
が証明できる9。しからば式 (9) の一般解は $A$ を積分常数として式 (11) で与克られる ${ }^{10) 。 ~}$

$u_{1}=\left(A_{1} e^{\gamma_{1} x_{1}}+A_{2} e^{-\gamma_{1} x_{1}}\right) \cos \delta_{1} x_{1}+\left(A_{3} e^{\gamma_{1} x_{1}}+A_{4} e^{-\gamma_{1} x_{1}}\right) \sin \delta_{1} x_{1}$,

ここに,

$$
\begin{aligned}
& r_{1}=\sqrt{\frac{1}{2}\left(\sqrt{\beta_{1}}+\frac{\alpha_{1}}{2}\right)}, \delta_{1}=\sqrt{\frac{1}{2}\left(\sqrt{\beta_{1}}-\frac{\alpha_{1}}{2}\right)}, \\
& \alpha_{1}=\frac{1}{k_{1}^{\prime} a_{1} G_{1}}\left(b_{1} K_{0}-\frac{w_{1} a_{1} n_{\mathrm{I}}^{2}}{q}\right), \beta_{1}=\frac{1}{E_{1} I_{1}}\left(b_{1} K_{0}-\frac{w_{1} a_{1} n_{\mathrm{I}}^{2}}{g}\right)
\end{aligned}
$$

式 (10) の一般解は $B$ を積分常数として次式でかける。

$u_{2}=B_{1} \cosh \delta_{2} x_{2}+B_{2} \sinh \delta_{2} x_{2}+B_{3} \cos \gamma_{2} x_{2}+B_{4} \sin \gamma_{2} x_{2}$,

ここに,

$$
\begin{aligned}
& r_{2}=\sqrt{\frac{1}{2}\left(\sqrt{\alpha_{2}^{2}+4 \beta_{2}}+\alpha_{2}\right)}, \quad \delta_{2}=\sqrt{\frac{1}{2}\left(\sqrt{\alpha_{2}^{2}+4 \beta_{2}}-\alpha_{2}\right)}, \\
& \alpha_{2}=\frac{w_{2} n_{\mathrm{I}}^{2}}{k_{2}{ }^{\prime} G_{2} g}, \quad \beta_{2}=\frac{w_{2} a_{2} n_{\mathrm{I}}^{2}}{E_{2} I_{2} g}
\end{aligned}
$$

(2) 振動数方程式 式 (1) 及び式 (8) から,

$$
\begin{aligned}
y_{1}= & y_{1 b}+y_{1 s}=\left(u_{1 b}+u_{1 s}\right) \cos (n t+\phi)=u_{1} \cos (n t+\phi), \\
\varphi_{1}= & \frac{\partial y_{1}}{\partial x_{1}}=\left(\frac{d u_{1 b}}{d x_{1}}+\frac{d u_{1 s}}{d x_{1}}\right) \cos (n t+\phi)=\frac{d u_{1}}{d x_{1}} \cos (n t+\phi), \\
M_{1}= & -E_{1} I_{1} \frac{\partial^{2} y_{1 b}}{\partial x_{1}{ }^{2}}=-E_{1} I_{1}\left(\frac{d^{2} u_{1}}{d x_{1}{ }^{2}}-\frac{d^{2} u_{1 s}}{d x_{1}{ }^{2}}\right) \cos (n t+\phi), \text { かつ式 }(2)_{2}: \\
& \frac{\partial S_{1}}{\partial x_{1}}-b_{1} K_{0} y_{1}=\frac{w_{1} a_{1}}{\mid g} \frac{\partial^{2} y_{1}}{\partial t^{2}} \text { より } \frac{d^{2} u_{1 s}}{d x_{1}{ }^{2}}=d_{1} u_{1}, \alpha_{1}: \text { 式 (11) }
\end{aligned}
$$

従つて $M_{1}, S_{1}$ は次式となる。

$$
\begin{aligned}
& M_{1}=-E_{1} I_{1}\left(\frac{d^{2} u_{1}}{d x_{1}{ }^{2}}-\alpha_{1} u_{1}\right) \cos (n t+\phi), \\
& S_{1}=\frac{\partial M_{1}}{\partial x_{1}}=-E_{1} I_{1}\left(\frac{d^{3} u_{1}}{d x_{1}{ }^{3}}-\alpha_{1} \frac{d u_{1}}{d x_{1}}\right) \cos (n t+\phi)
\end{aligned}
$$

一方地上部 $\mathrm{BC}$ は $K_{0}=0$ であるととを考虑して，

$$
\left.\begin{array}{l}
M_{2}=-E_{2} I_{2}\left(\frac{d^{2} u_{2}}{d x_{2}{ }^{2}}+\alpha_{2} u_{2}\right) \cos (n t+\phi), \\
S_{2}=-E_{2} I_{2}\left(\frac{d^{3} u_{2}}{d x_{2}{ }^{3}}+\alpha_{22} \frac{d u_{2}}{d x_{2}}\right) \cos (n t+\phi)
\end{array}\right\}
$$

次境界条件及び接続条件は図一1から，

1) 最下端 A, $x_{1}=0: M_{1}=0, S_{1}=0$,

2）地盤面 $\mathrm{B}, x_{1}=d$ かつ $x_{2}=0$ :

$$
y_{1}=y_{2}, \varphi_{1}=\varphi_{2}, M_{1}=M_{2}, S_{1}=S_{2}
$$

3) 頂 部 C, $x_{2}=h: M_{2}=0, S_{2}=-\frac{W}{g} \frac{\partial^{2} y_{2}}{\partial t^{2}}$

である。式 (8)，(11)，(12) の $y ， u$ から式 (13)，(14)，(15)の $\varphi, M, S$ 算出し，これらを式 (16) の 8 個の条件式に代入すると, 式 (11)，(12) の $A, B$ 個の積分常数を消去することができる。この計算を遂行し て整理すると結局次の振動数方程式をうる。

$$
\begin{aligned}
& F\left(n_{\mathrm{I}}\right)=\left\{\lambda_{1}\left(\delta_{2}^{2}+\alpha_{2}\right) \cosh \delta_{2} h+\lambda_{2}\left(\delta_{2}^{2}+\alpha_{2}\right) \sinh \delta_{2} h-\lambda_{3}\left(\gamma_{2}^{2}-\alpha_{2}\right) \cos \gamma_{2} h-\lambda_{4}\left(\gamma_{2}^{2}-\alpha_{2}\right) \sin \gamma_{2} h\right\} \\
& \times\left[\begin{array}{c}
\mu_{1}\left\{\delta_{2}\left(\delta_{2}^{2}+\alpha_{2}\right) \sinh \delta_{2} h+W_{n} \cosh \delta_{2} h\right\}+\mu_{2}\left\{\delta_{2}\left(\delta_{2}{ }^{2}+\alpha_{2}\right) \cosh \delta_{2} h+W_{n} \sinh \delta_{2} h\right\}^{-} \\
+\mu_{3}\left\{\gamma_{2}\left(\gamma_{2}{ }^{2}-\alpha_{2}\right) \sin \gamma_{2} h+W_{n} \cos \gamma_{2} h\right\}+\mu_{4}\left\{-\gamma_{2}\left(\gamma_{2}{ }^{2}-\alpha_{2}\right) \cos \gamma_{2} h+W_{n} \sin \gamma_{2} h\right\}
\end{array}\right] \\
& -\left\{\mu_{1}\left(\delta_{2}^{2}+\alpha_{2}\right) \cosh \delta_{2} h+\mu_{2}\left(\delta_{2}^{2}+\alpha_{2}\right) \sinh \delta_{2} h-\mu_{3}\left(\gamma_{2}{ }^{2}-\alpha_{2}\right) \cos \gamma_{2} h-\mu_{4}\left(r_{2}^{2}-\alpha_{2}\right) \sin \gamma_{2} h\right\} \\
& \times\left[\begin{array}{l}
\lambda_{1}\left\{\delta_{2}\left(\delta_{2}^{2}+\alpha_{2}\right) \sinh \delta_{2} h+W_{n} \cosh \delta_{2} h\right\}+\lambda_{2}\left\{\delta_{2}\left(\delta_{2}^{2}+\alpha_{2}\right) \cosh \delta_{2} h+W_{n} \sinh \delta_{2} h\right\} \\
+\lambda_{3}\left\{\gamma_{2}\left(\gamma_{2}{ }^{2}-\alpha_{2}\right) \sin \gamma_{2} h+W_{n} \cos \gamma_{2} h\right\}+\lambda_{4}\left\{-\gamma_{2}\left(\gamma_{2}{ }^{2}-\alpha_{2}\right) \cos \gamma_{2} h+W_{n} \sin \gamma_{2} h\right\}
\end{array}\right] \\
& =0
\end{aligned}
$$

$$
\begin{array}{ll}
\lambda_{1}=\Delta_{1}\left\{j\left(\gamma_{2}^{2}-\alpha_{2}\right)+e_{i} l\right\}, & \lambda_{2}=\Delta_{3}\left\{e_{i} m+k\left(\gamma_{2}^{2}-\alpha_{2}\right)\right\}, \\
\lambda_{3}=\Delta_{1}\left\{j\left(\delta_{2}{ }^{2}+\alpha_{2}\right)-e_{i} l\right\}, & \lambda_{4}=\Delta_{2}\left\{k\left(\delta_{2}{ }^{2}+\alpha_{2}\right)-e_{i} m\right\},
\end{array}
$$


$\mu_{1}=\Delta_{1}\left\{j^{\prime}\left(r_{2}^{2}-\alpha_{2}\right)+e_{i} l^{\prime}\right\}, \quad \mu_{2}=\Delta_{3}\left\{e_{i} m^{\prime}+k^{\prime}\left(r_{2}^{2}-\alpha_{2}\right)\right\}$,

$\mu_{3}=\Delta_{1}\left\{j^{\prime}\left(\delta_{2}{ }^{2}+\alpha_{2}\right)-e_{i} l^{\prime}\right\}, \quad \mu_{4}=\Delta_{2}\left\{k^{\prime}\left(\delta_{2}{ }^{2}+\alpha_{2}\right)-e_{i} m^{\prime}\right\}$,

$\Delta_{1}=1 / \sqrt{\alpha_{2}{ }^{2}+4 \beta_{2}}, \quad \Delta_{2}=\Delta_{1} / r_{2}, \quad \Delta_{3}=\Delta_{1} / \delta_{2}$,

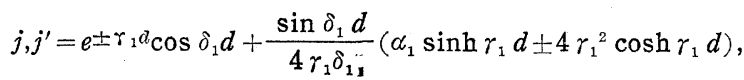

$k, k^{\prime}= \pm e^{ \pm \gamma_{1} a}\left(\gamma_{1} \cos \delta_{1} d \mp \delta_{1} \sin \delta_{1} d\right)$

$+\frac{1}{4 r_{1} \delta_{1}}\left\{r_{1}\left(\alpha_{1} \sin \delta_{1} d \pm 4 r_{1} \delta_{1} \cos \delta_{1} d\right) \cosh r_{1} d+\left(\alpha_{1} \delta_{1} \cos \delta_{1} d \pm 4 \gamma_{1}{ }^{3} \sin \delta_{1} d\right) \sinh r_{1} d\right\}$,

$l, l^{\prime}=\frac{1}{8 \gamma_{1} \delta_{1}}\left\{\begin{array}{l}4 \alpha_{1} \gamma_{1}\left(\delta_{1} \cos \delta_{1} d \mp \gamma_{1} \sin \delta_{1} d\right) \cosh \gamma_{1} d \\ -\left(\alpha_{1}^{2} \sin \delta_{1} d \mp 16 \gamma_{1}^{3} \delta_{1} \cos \delta_{1} d\right) \sinh \gamma_{1} d-4 \gamma_{1} \delta_{1} e^{ \pm r_{1} d}\left(\alpha_{1} \cos \delta_{1} d \pm 4 \gamma_{1} \delta_{1} \sin \delta_{1} d\right)\end{array}\right\}$.

$m, m^{\prime}= \pm \frac{1}{4 r_{1} \delta_{1}}$

$\times\left\{\begin{array}{l}\delta_{1}\left(\alpha_{1}{ }^{2}+2 \beta_{1}-4 \alpha_{1} \gamma_{1}^{2}\right) \cosh \gamma_{1} d \cos \delta_{1} d+\gamma_{1}\left(\alpha_{1}^{2}-2 \beta_{1}-4 \alpha_{1} \gamma_{1}{ }^{2}\right) \sinh \gamma_{1} d \sin \delta_{1} d \\ +2 \sqrt{\beta_{1} \delta_{1}} e^{ \pm \gamma_{1} d}\left(\alpha_{1} \cos \delta_{1} d-2 \gamma_{1}{ }^{2} \cos \delta_{1} d \mp 2 \gamma_{1} \delta_{1} \sin \delta_{1} d\right)+\alpha_{1} \sqrt{\beta_{1}} e^{ \pm \gamma_{1} d}\left(\delta_{1} \cos \delta_{1} d \mp \gamma_{1} \sin \delta_{1} d\right)\end{array}\right\}$,

ただし複号同順， $e_{i}=E_{1} I_{1} / E_{2} I_{2}, \quad W_{n}=W n_{\mathrm{I}}^{2} /\left(E I_{2} g\right)$,

$\alpha_{1}, \beta_{1}, \gamma_{1}, \delta_{1}=f_{1}\left(n_{1}\right):$ 式 (11), $\alpha_{2}, \beta_{2}, \gamma_{2}, \delta_{2}=f_{2}\left(n_{1}\right):$ 式 (12)

式 (17) を満足する $n_{\mathrm{I}}$ が曲げセン断動摇の振動数である。

（3）正規函数 振動形状る決定する正規函数 $u$ 及び $u_{2}$ 注式（16）の条件式を用いて式 (11)，(12）の積分 常数 $A, B$ 相互間の比を決定するととにより次式をうる。

$u_{1}=A_{1}\left[\left(e^{\gamma_{1} x_{1}}-s e^{-\gamma_{1} x_{1}}\right) \cos \delta_{1} x_{1}+\left\{\left(i-s i^{\prime}\right) e^{\gamma_{1} x_{1}}+\left(s i-i^{\prime}\right) e^{-\gamma_{1} x_{1}}\right\} \sin \delta_{1} x_{1}\right]$,

ここに,

$i, i^{\prime}=\left(\alpha_{1} \pm 4 \gamma_{1}^{2}\right) / 8 \gamma_{1} \delta_{1}, s=\Sigma_{1} / \Sigma_{3}$,

$\Sigma_{1}=\lambda_{1}\left(\delta_{2}{ }^{2}+\alpha_{2}\right) \cosh \delta_{2} h+\lambda_{2}\left(\delta_{2}{ }^{2}+\alpha_{2}\right) \sinh \delta_{2} h-\lambda_{3}\left(\gamma_{2}{ }^{2}-\alpha_{2}\right) \cos \gamma_{2} h-\lambda_{4}\left(\gamma_{2}{ }^{2}-\alpha_{2}\right) \sin \gamma_{2} h$,

$\Sigma_{3}=\mu_{1}\left(\delta_{2}{ }^{2}+\alpha_{2}\right) \cosh \delta_{2} h+\mu_{2}\left(\delta_{2}{ }^{2}+\alpha_{2}\right) \sinh \delta_{2} h-\mu_{3}\left(\gamma_{2}{ }^{2}-\alpha_{2}\right) \cos \gamma_{2} h-\mu_{4}\left(\gamma_{2}{ }^{2}-\alpha_{2}\right) \sin \gamma_{2} h$

$u_{2}=A_{1}\left\{\left(\lambda_{1}-s \mu_{1}\right) \cosh \delta_{2} x_{2}+\left(\lambda_{2}-s \mu_{2}\right) \sinh \delta_{2} x_{2}+\left(\lambda_{3}-s \mu_{3}\right) \cos \gamma_{2} x_{2}+\left(\lambda_{4}-s \mu_{4}\right) \sin \gamma_{2} x_{2}\right\}$

式 (19)の $s$ は式 (18)，式 (18)，(19）の $\lambda, \mu$ 等は式 (17) 飞示した值である。

\section{4. 曲げおよびセン断動摇振動}

（1）曲げ動摇振動 この場合は回転慣性及びセン断の影響を無視するので, 式 (1) で $y_{r}=y_{s}=0$ かつ $\varphi_{r}=$ $\varphi_{s}=0$ と招くと，式 (6)，(7) 飞相当して次の基礎方程式をうる。

$$
\left.\begin{array}{l}
\frac{\partial^{4} y_{1 b}}{\partial x_{1}{ }^{4}}+\frac{b_{1} K_{0}}{E_{1} I_{1}} y_{1 b}+\frac{w_{1} a_{1}}{E_{1} I_{1} g} \frac{\partial^{2} y_{1 b}}{\partial t^{2}}=0, \\
\frac{\partial^{4} y_{2 b}}{\partial x_{2}{ }^{4}}+\frac{w_{2} a_{2}}{E_{2} I_{2} g} \frac{\partial^{2} y_{2 b}}{\partial t^{2}}=0
\end{array}\right\}
$$

一方曲げ振動では $\varphi_{s}=0$ であるととから,$G=S / \varphi_{s} a=S / 0 \rightarrow \infty$ となるので, 式 (6), (7) で $G_{1} \rightarrow \infty, G_{2} \rightarrow \infty$ と嗒くと，直接代式 (20) の結果をうることができる。

さて式 (8) と同椂と招き, 乙れを式 (20) 飞代入して時間函数を消去すると, 式 (9)，(10）飞相当して次式 をうる。

$$
\begin{aligned}
& \frac{d^{4} u_{1 b}}{d x_{1}{ }^{4}}+\frac{1}{E_{1} I_{1}}\left(b_{1} K_{0}-\frac{w_{1} a_{1}}{g} n_{b}^{2}\right) u_{1 b}=0, \\
& \frac{d^{4} u_{2 b}}{d x_{2}{ }^{4}}-\frac{w_{2} a_{2} n_{b}^{2}}{\llbracket E_{2} I_{2} g} u_{2 b}=0
\end{aligned}
$$

ここで 3. (1) の場合と同様に $\left(b_{1} K_{0}-w_{1} a_{1} n_{b \mathrm{I}}^{2} / g\right)>0$ であるととに注意すると, 式 (21) の一般解は式 (22) で与えられる11。

ここに,

$$
\begin{aligned}
& u_{1 b}=\frac{1}{2}\left\{\left(A_{1} e^{\beta_{1 b} x_{1}}+A_{2} e^{-\beta_{1 b} x_{1}}\right) \cos \beta_{1 b} x_{1}+\left(A_{3} e^{\beta_{1 b} x_{1}}+A_{4} e-\beta_{1 b} x_{1}\right) \sin \beta_{1 b} x_{1}\right\}, \\
& u_{2 b}=B_{1} \cosh \beta_{2 b} x_{2}+B_{2} \sinh \beta_{2 b} x_{2}+B_{3} \cos \beta_{2 b} x_{2}+B_{4} \sin \beta_{2 b} x_{2}
\end{aligned}
$$

$$
\beta_{1 b}=\sqrt[4]{\frac{1}{4 E_{1} I_{1}}\left(b_{1} K_{0}-\frac{w_{1} a_{1}}{g} n_{b \mathrm{1}}^{2}\right)}=\sqrt[4]{\frac{1}{4} \beta_{1}},
$$




$$
\beta_{2 b}=\sqrt{\frac{w_{2} a_{2} n_{b}^{2}}{E_{2} I_{2} g}}=\sqrt{\beta_{2}}, \beta_{1}: \text { 式 (11), } \beta_{2} \text { : 式 (12) }
$$

しかるに $M=-E_{1} I_{1} \cdot \partial^{2} y_{b} / \partial x^{2}, S=\partial M / \partial x$ であので, 式 (16) の条件式からただらに式 (22) の積分常数 $A, B$ を消去するととができる。この計算そ准めると結局次の振動数方程式が兄られる。

$$
\begin{aligned}
& F\left(n_{b \mathrm{I}}\right)=\left(\lambda_{1 b} \cosh \beta_{2 b} h+\lambda_{2 b} \sinh \beta_{2 b} h-\lambda_{3 b} \cos \beta_{2 b} h-\lambda_{4 b} \sin \beta_{2 b} h\right) \\
& \times\left\{\begin{array}{l}
\left.\mu_{1 b} \sinh \beta_{2 b} h+W_{n} \cosh \right)+\mu_{2 b}\left(\cosh \beta_{2 b} h+W_{n} \sinh \beta_{2 b} h\right) \\
+\mu_{3 b}\left(\sin \beta_{2 b} h+W_{n} \cos \beta_{2 b} h\right)-\mu_{4 b}\left(\cos \beta_{2 b} h-W_{n} \sin \beta_{2 b} h\right)
\end{array}\right\} \\
& -\left(\mu_{1 b} \cosh \beta_{2 b} h+\mu_{2 b} \sinh \beta_{2 b} h-\mu_{3 b} \cos \beta_{2 b} h-\mu_{4} \sin \beta_{2 b} h\right) \\
& \times\left\{\begin{array}{l}
\lambda_{1 b}\left(\sinh \beta_{2 b} h+W_{n} \cosh \beta_{2 b} h\right)+\lambda_{2 b}\left(\cosh \beta_{2 b} h+W_{n} \sinh \beta_{2 b} h\right) \\
+\lambda_{3 b}\left(\sin \beta_{2 b} h+W_{n} \cos \beta_{2 b} h\right)-\lambda_{4 b}\left(\cos \beta_{2 b} h-W_{1 h} \sin \beta_{2 b} h\right)
\end{array}\right\} \\
& =0
\end{aligned}
$$

ここ,

$$
\begin{aligned}
\lambda_{1 b}, \lambda_{3 b}= & \frac{1}{2}\left(e^{\beta_{1 b} d} \cos \beta_{1 b} d+\cosh \beta_{1 b} d \sin \beta_{1 b} d\right) \\
& \mp e_{i} \beta^{2}\left(e^{\beta_{1 b} d} \sin \beta_{1 b} d-\sinh \beta_{1 b} d \cos \beta_{1 b} d\right), \\
\lambda_{2 b}, \lambda_{4 b}= & \frac{\beta}{2}\left\{e^{\beta_{1 b} d}\left(\cos \beta_{1 b} d-\sin \beta_{1 b} d\right)+\cosh \beta_{1 b} d \cos \beta_{1 b} d+\sinh \beta_{1 b} d \sin \beta_{1 b} d\right\} \\
& \mp e_{i} \beta^{3}\left\{e^{\beta_{1 b} d}\left(\cos \beta_{1 b} d+\sin \beta_{1 b} d\right)-\cosh \beta_{1 b} d \cos \beta_{1 b} d+\sinh \beta_{1 b} d \sin \beta_{1 b} d\right\}, \\
\mu_{1 b}, \mu_{3 b}= & \frac{1}{2}\left(e^{-\beta_{1 b} d} \cos \beta_{1 b} d-\cosh \beta_{1 b} d \sin \beta_{1 b} d\right) \\
& \pm e_{i} \beta^{2}\left(e^{-\beta_{1 b} d} \sin \beta_{1 b} d-\sinh \beta_{1 b} d \cos \beta_{1 b} d\right), \\
\mu_{2 b}, \mu_{4 b}= & -\frac{\beta}{2}\left\{e^{-\beta_{1 b} d}\left(\cos \beta_{1 b} d+\sin \beta_{1 b} d\right)+\cosh \beta_{1 b} d \cos \beta_{1 b} d+\sinh \beta_{1 b} d \sin \beta_{1 b} d\right\} \\
& \pm e_{i} \beta^{3}\left\{e-\beta_{1 b} d\left(\cos \beta_{1 b} d-\sin \beta_{1 b} d\right)-\cosh \beta_{1 b} d \cos \beta_{1 b} d+\sinh \beta_{1 b} d \sin \beta_{1 b} d\right\},
\end{aligned}
$$

複号同順, $e_{i}=E_{1} I_{1} / E_{2} I_{2}, W_{n}=W n_{b}^{2} /\left(E_{2} I_{2} \beta_{2 b}{ }^{3} g\right)$,

$$
\beta=\beta_{1 b} \mid \beta_{2 b}, \beta_{1 b}, \beta_{2 b} \text { : 式 }
$$

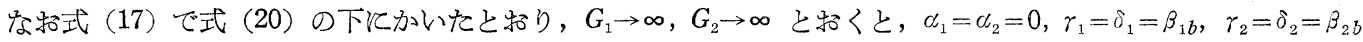
となつて式 (23) となることはいうまでもない。

次に 3.（3）と同様に式（22）の積分常数 $A, B$ 相互間の比を式（16）から決定できる。この結果正規函数と して次式が算出される。

$$
\begin{aligned}
u_{1 b}= & \frac{A_{1}}{2}\left\{\left(e^{\beta_{1 b} x_{1}}-s_{b} e^{-\beta_{1 b} x_{1}}\right) \cos \beta_{1 b} x_{1}+\left(1+s_{b}\right) \cosh \beta_{1 b} x_{1} \sin \beta_{1 b} x_{1}\right\}, \\
u_{2 b}= & \frac{A_{1}}{2}\left\{\left(\lambda_{1 b}-s_{b} \mu_{1 b}\right) \cosh \beta_{2 b} x_{2}+\left(\lambda_{2 b}-s_{b} \mu_{2 b}\right) \sinh \beta_{2 b} x_{2}\right. \\
& \left.+\left(\lambda_{3 b}-s_{b} \mu_{3 b}\right) \cos \beta_{2 b} x_{2}+\left(\lambda_{4 b}-s_{b} \mu_{4 b}\right) \sin \beta_{2 b} x_{2}\right\}, \\
\tau, s_{b}= & \Sigma_{1 b} / \Sigma_{3 b}, \\
\Sigma_{1 b}= & \lambda_{1 b} \cosh \beta_{2 b} h+\lambda_{2 b} \sinh \beta_{2 b} h-\lambda_{3 b} \cos \beta_{2 b} h-\lambda_{4 b} \sin \beta_{2 b} h, \\
\Sigma_{3 b}= & \mu_{1 b} \cosh \beta_{2 b} h+\mu_{2 b} \sinh \beta_{2 b} h-\mu_{3 b} \cos \beta_{2 b} h-\mu_{4 b} \sin \beta_{2 b} h
\end{aligned}
$$

ここマ, $s_{b}=\Sigma_{1 b} / \Sigma_{3 b}$,

（2）七ン断動摇振動 この場合は式（1）で $y_{s}$ まは $\varphi_{s}$ のみをとので，基礎方程式は容易に次のと招り かける。

$$
\left.\begin{array}{c}
k_{1}{ }^{\prime} a_{1} G_{1} \frac{\partial^{2} y_{1 s}}{\partial x_{1}{ }^{2}}-b_{1} K_{0} y_{1 s}-\frac{w_{1} a_{1}}{g} \frac{\partial^{2} y_{1 s}}{\partial t^{2}}=0, \\
k_{2}{ }^{\prime} G_{2} \frac{\partial^{2} y_{2 s}}{\partial x_{2}{ }^{2}}-\frac{w_{2}}{g} \frac{\partial^{2} y_{2 s}}{\partial t^{2}}=0
\end{array}\right\}
$$

またセン断振動では曲げ変形 $y_{b}=0$ であるので長さ $x$ 方向のヒズミ $\Delta l / l$ は起らない。従つて $E=P l /(a \Delta l)$ $=P l / 0 \rightarrow \infty$ ，すなわち式 (6)，(7) で直接 $E_{1} \rightarrow \infty, E_{2} \rightarrow \infty$ と抏くことによつても式 (25) が容易にえられる*。 次に式 (8) と同様に沶いてこれを式 (25) に代大して，時間函数を消去すると式（26）となる。

*式 (6)，(7) をそれぞれ $E_{1} I_{1}, E_{2} I_{2}$ で除したのち $E_{1} \rightarrow \infty ， E_{2} \rightarrow \infty$ とするととはいうまでるない。 


$$
\begin{aligned}
& \frac{d^{2} u_{1 s}}{d x_{1}{ }^{2}}-\frac{1}{k_{1}{ }^{\prime} a_{1} G_{1}}\left(b_{1} K_{0}-\frac{w_{1} a_{1}}{g} n_{s}{ }^{2}\right) u_{1 s}=0, \\
& \frac{d^{2} u_{2 s}}{d x_{2}{ }^{2}}+\frac{w_{2} n_{s}{ }^{2}}{k_{2}{ }^{\prime} G_{2} g} u_{2 s}=0
\end{aligned}
$$

ここで 3.（1），4（1）と同様に $\left(b_{1} K_{0}-w_{1} a_{1} n_{s} \mathrm{I}^{2} / g\right)>0$ であることに注意すると,式 (26) の一般解は式 (27) で表わされる。

$$
\begin{aligned}
& u_{1 s}=A_{1} \cosh \alpha_{1 s} x_{1}+A_{2} \sinh \alpha_{1 s} x_{1}, \\
& u_{2 s}=B_{1} \cos \alpha_{2 s} x_{2}+B_{2} \sin \alpha_{2 s} x_{2},
\end{aligned}
$$

ここそ,

$$
\begin{aligned}
& \alpha_{1 s}=\sqrt{\frac{1}{k_{1}{ }^{\prime} a_{1} G_{1}}\left(b_{1} K_{0}-\frac{w_{1} a_{1}}{g} n_{s \mathrm{I}}^{2}\right)}=\sqrt{\alpha_{1}}, \\
& \alpha_{2 s}=\sqrt{\frac{w_{2} n_{s \mathrm{I}}^{2}}{k_{2}{ }^{\prime} G_{2} g}}=\sqrt{\alpha_{2}}, \alpha_{1}: \text { 式 (11), } \alpha_{2}: \text { 式 (12) }
\end{aligned}
$$

境界条件及び接続条件は $S=k^{\prime} a G \partial y_{s} / \partial x$ であることに留意すると，図一1 から式 (16) と同様に，
1) $A, x_{1}=0: S_{1}=0$,
2) $B, x_{1}=d$ かつ $x_{2}=0: u_{1 s}=u_{2 s}, S_{1}=S_{2}$
3) $C, x_{2}=h: S_{2}=-(W / g) \cdot \partial^{2} y_{2 . s} / \partial t^{2}$

である。この 4 条件から式 (27) の $A, B 4$ 個の積分常数を消去すると，振動数方程式として式（29）をうる。 $\left.F\left(n_{s \mathrm{I}}\right)=\alpha_{1 s}\left(\alpha_{2 s} \cos \alpha_{2 s} h-W_{n} \sin \alpha_{2 s} h\right) \tanh \alpha_{1 s} d-\alpha_{2 s}\left(\alpha_{2 s} \sin \alpha_{2 s} h+W_{n} \cos \alpha_{2 s} h\right)=0,1\right)$

ここに, $W_{n}=W n_{s \mathrm{I}}^{2} /\left(k_{2}{ }^{\prime} a_{2} G_{2} g\right), \alpha_{1 s}, \alpha_{2 s}$ : 式 (27)

次に正規函数は式 (27) の $A, B$ 間の比を式 (28) の条件式によつて決定することにより次式で求まる。

$$
\left.\begin{array}{l}
u_{1 s}=A_{1} \cosh \alpha_{1 s} x_{1}, \\
u_{2 s}=A_{1} \cosh \alpha_{1 s} d\left(\cos \alpha_{2 s} x_{2}+\frac{\alpha_{2 s} \sin \alpha_{2 s} h+W_{n} \cos \alpha_{2 s} h}{\alpha_{2 s} \cos \alpha_{2 s} h-W_{n} \sin \alpha_{2 s} h} \sin \alpha_{2 s} x_{2}\right)
\end{array}\right\} .
$$

\section{5. 固有周期に関する近似計算法}

3. 及び 4. の振動数方程式, 式 (17)，(23) 及び（29）加 ら振動数 $n_{\mathrm{I}}$ を算出するととはかなり煩雑であるので，周知の Rayleigh 法飞より近似計算を試みる。便宜上図一2のように 橋脚頂部に水平集中荷重 $b_{2} P\left(b_{2}\right.$ : 橋脚頂部奥行巾) を作用さ せた場合の静変位曲線 $\eta_{1}, \eta_{2}$ を振動曲線 $y_{1}, y_{2}$ 亿相似である と仮定する。

(1) 曲げ動摇振動 図一2 (1) の $\eta_{1 b}, \eta_{2 b}$ は式 (22)の $u_{1 b}$, $u_{2 b}$ で $n_{b \mathrm{I}} \rightarrow 0$ と括け代よい。この $\eta_{1 b}, \eta_{2 b}$ を用いた固有周期 $T_{R b}$ 著者がすで算出していると和り次式で与えられる ${ }^{12)}$ 。

$$
\left.\begin{array}{l}
T_{R b}=2 \pi \sqrt{\frac{1}{\eta_{c b} b_{2} P g}\left(w_{1} a_{1} \int_{0}^{d} \eta_{1 b}{ }^{2} d x_{1}+w_{2} a_{2} \int_{0}^{h} \eta_{2 b}{ }^{2} d x_{2}+W \eta_{c b}{ }^{2}\right)}, \\
\text { 詳紐は参考文献欄 12), 式 (8), (8) } 1 \text { 参照。 }
\end{array}\right\} .
$$

（2）セン断動摇振動 図一2（2）の $\eta_{1 s} ， \eta_{2 s}$ は式（27）の $u_{1 s}, u_{2 s}$ で $n_{s \mathrm{I}} \rightarrow 0$ と招き，式（28）の条件を满 足するように積分常数を決定すると次式をうる。

$$
\begin{aligned}
& \eta_{1 s}=\frac{b_{2} P}{\alpha_{0} k_{2}{ }^{\prime} a_{2} G_{2} \sinh \alpha_{0} d} \cosh \alpha_{0} x_{1}, \\
& \eta_{2 s}=\frac{b_{2} P}{k_{2}{ }^{\prime} a_{2} G_{2}} x_{2}+\frac{\operatorname{coth} \alpha_{0} d}{\alpha_{0} k_{2}{ }^{\prime} a_{2} G_{2}} b_{2} P, \alpha_{0}=\sqrt{\frac{b_{1} K_{0}}{k_{1}{ }^{\prime} a_{1} G_{1}}}
\end{aligned}
$$

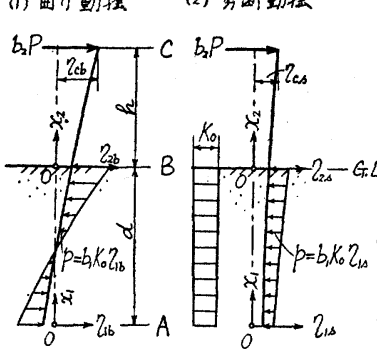

(3)純鱾拱

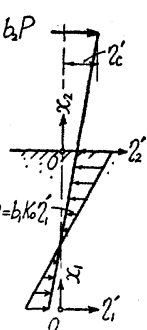

式 (32) を用いた固有周期 $T_{R s}$ は式 (33) となる。

$$
\begin{array}{ll} 
& T_{R s}=2 \pi \sqrt{\frac{1}{\eta_{c s} b_{2} P g}\left(w_{1} a_{1} \int_{0}^{d} \eta_{1 s}{ }^{2} d x_{1}+w_{2} a_{2} \int_{0}^{h} \eta_{2 s}{ }^{2} d x_{2}+W \eta_{c s}{ }^{2}\right),} \\
\text { ここV, } & \eta_{c s}=\frac{b_{2} P}{k_{2}{ }^{\prime} a_{2} G_{2}}\left(h+\frac{\operatorname{coth} \alpha_{0} d}{\alpha_{0}}\right), \\
& \int_{0}^{a} \eta_{1 s^{2}} d x_{1}=\frac{w_{1} a_{1}}{2 \alpha_{0}{ }^{3}}\left(\frac{b_{2} P}{k_{2}{ }^{\prime} a_{2} G_{2}}\right)^{2}\left(\operatorname{coth} \alpha_{0} d+\frac{\alpha_{0} d}{\sinh ^{2} \alpha_{0} d}\right),
\end{array}
$$




$$
\int_{0}^{h} \eta_{2 s}{ }^{2} d x_{2}=h\left(\frac{b_{2} P}{k_{2}{ }^{\prime} a_{2} G_{2}}\right)^{2}\left(\frac{h^{2}}{3}+\frac{h}{\alpha_{0}} \operatorname{coth} \alpha_{0} d+\frac{1}{\alpha_{0}{ }^{2}} \operatorname{coth}^{2} \alpha_{0} d\right)
$$

(3) 曲げセン断動摇振動 5 (1)，(2) と同様と式 (11) 及び (12) で $n \rightarrow 0$ と括けげよいが， $\eta_{1}, \eta_{2}$ 自身 及びその自乗の定積分を新しく計算するととは必ずしも簡単ではいので，乙こでは便宜上 $\eta_{1}=\eta_{1 b}+\eta_{1 s}, \eta_{2}=\eta_{2 b}+$ $n_{2 s}$ として上記（1）（2）の結果を合成することにする。すると固有周期 $T_{R}$ は次のようとかき表わされる。

$$
T_{R}=2 \pi \sqrt{\frac{1}{\left(\eta_{C b}+\eta_{C s}\right) b_{2} P g}\left(\nu_{b}+\nu_{s}+2 \nu_{b s}\right)}
$$

ここに,

$$
\begin{aligned}
& \nu_{b}=w_{1} a_{1} \int_{0}^{a} \eta_{1 b^{2}} d x_{1}+w_{2} a_{2} \int_{0}^{h} \eta_{2 b}^{2} d x_{2}+W \eta_{C b}{ }^{2}: \text { 式 (31)， } \\
& \nu_{s}=w_{1} a_{1} \int_{0}^{a} \eta_{1 s}^{2} d x_{1}+w_{2} a_{2} \int_{0}^{h} \eta_{2 s}^{2} d x_{2}+W \eta_{C s^{2}}: \text { 式 (33)， } \\
& \nu_{b s}=w_{1} a_{1} \int_{0}^{a} \eta_{1 b} \eta_{1 s} d x_{1}+w_{2} a_{2} \int_{0}^{h} \eta_{2 b} \eta_{2 s} d x_{2}+W \eta_{C b} \eta_{C s}, \\
& \int_{0}^{a} \eta_{1 b} \eta_{1 s} d x_{1}=\frac{b_{2} P}{4 \alpha_{0} k_{2}{ }^{\prime} a_{2} G_{2} \sinh \alpha_{0} d}\left\{\frac{1}{\beta_{0}{ }^{2}+\gamma_{0}{ }^{2}} f\left(\beta_{0}, \gamma_{0}\right)+\frac{1}{\beta_{0}{ }^{2}+\delta_{0}{ }^{2}} f\left(\beta_{0}, \delta_{0}\right)\right\} \text {, } \\
& f\left(\beta_{0}, \gamma_{0}\right)=\gamma_{0} \cos \beta_{0} d\left(A_{1} e^{\gamma_{0} d}-A_{2} e^{-\gamma_{0} d}\right)+\beta_{0} \sin \beta_{0} d\left(A_{1} e^{\gamma_{0} d}+A_{2} e^{-\gamma_{0} d}\right) \\
& -\gamma_{0}\left(A_{1}-A_{2}\right)+2 A_{3}\left(\gamma_{0} \sin \beta_{0} d \sinh \gamma_{0} d-\beta_{0} \cos \beta_{0} d \cosh \gamma_{0} d+\beta_{0}\right) \text {, } \\
& f\left(\beta_{0}, \delta_{0}\right)=\delta_{0} \cos \beta_{0} d\left(A_{2} e^{\delta_{0} d}-A_{1} e^{-\delta_{0} d}\right)+\beta_{0} \sin \beta_{0} d\left(A_{2} e^{\delta_{0} d}+A_{1} e^{-\delta_{0} d}\right) \\
& +\delta_{0}\left(A_{1}-A_{2}\right)+2 A_{3}\left(\delta_{0} \sin \beta_{0} d \sinh \delta_{0} d-\beta_{0} \cos \beta_{0} d \cosh \delta_{0} d+\beta_{0}\right) \text {, } \\
& \int_{0}^{h} \eta_{2 b} \eta_{2 s} d x_{2}=\frac{h b_{2} P}{k_{2}{ }^{\prime} a_{2} G_{2}}\left\{\begin{array}{l}
h\left(B_{1} h^{3} / 5+B_{2} h^{2} / 4+B_{3} h / 3+B_{4} / 2\right) \\
+\frac{\operatorname{coth} \alpha_{0} d}{\alpha_{0}}\left(B_{1} h^{3} / 4+B_{2} h^{2} / 3+B_{3} h / 2+B_{4}\right)
\end{array}\right\} \\
& \eta_{C b} \eta_{C s}=\frac{b_{2} P}{k_{2}{ }^{\prime} a_{2} G_{2}}\left(h+\frac{1}{\alpha_{0}} \operatorname{coth} \alpha_{0} d\right)\left(B_{1} h^{3}+B_{2} h^{2}+B_{3} h+B_{4}\right) \text {, } \\
& A_{1} \sim A_{4}, B_{1} \sim B_{4} \text { 䚾は } P \text { を含む参考文献闌 12) pp 59-60の表一1 から沃定される。 }
\end{aligned}
$$

(4) 純動摇振動 この場合は橋脚井筒を完全な剛体と考えるので, 図一2（3）の静曲線 $\eta_{1}{ }^{\prime}, \eta_{2}{ }^{\prime}$ は当然直線 となる。これ《対する固有周期 $T_{R}{ }^{\prime}$ は著者の式 ${ }^{13)}$ で $K\left(x_{1}\right)$ の分布指数 $n=0$ と括けばよい $\left(\because K\left(x_{1}\right)=K_{A}(1\right.$ $\left.-x_{1} / d\right)^{n}$ で $\left.n=0 \therefore K\left(x_{1}\right)=K_{A} \rightarrow K_{0}\right)$ 。とうすると $T_{R}{ }^{\prime}$ \& $h / d=\delta_{0}$ と招いて容易次式でかける。

$$
T_{R^{\prime}}=2 \pi \sqrt{\frac{1}{b_{1} K_{0} g} \frac{w_{1} a_{1}\left(3 \delta_{0}{ }^{2}+3 \delta_{0}+1\right)+w_{2} a_{2} \delta_{0}\left(12 \delta_{0}{ }^{4}+30 \delta_{0}{ }^{3}+33 \delta_{0}{ }^{2}+18 \delta_{0}+4\right)}{3 \delta_{0}{ }^{2}+3 \delta_{0}+1}} .
$$

\section{6. 数値計算例}

本文の理論解はかなり複雑であるので，これを定性的数值計算することは非常に多くの労力を要する。そこ でここでは実在橋脚井筒のうちから a）比較的セン断効果の小さいと思われる中角橋脚：図一3 (1) 及び b) 比 較的セン断効果の大きいと思われる九頭龍橋脚井筒：図一4（1）の 2 個を代表的飞選えだ。な报簡単のため 1 . 末尾にかいたと括りWを除外した。

図一3 正規函数形 $u$ の計算結果 (中角橋脚)

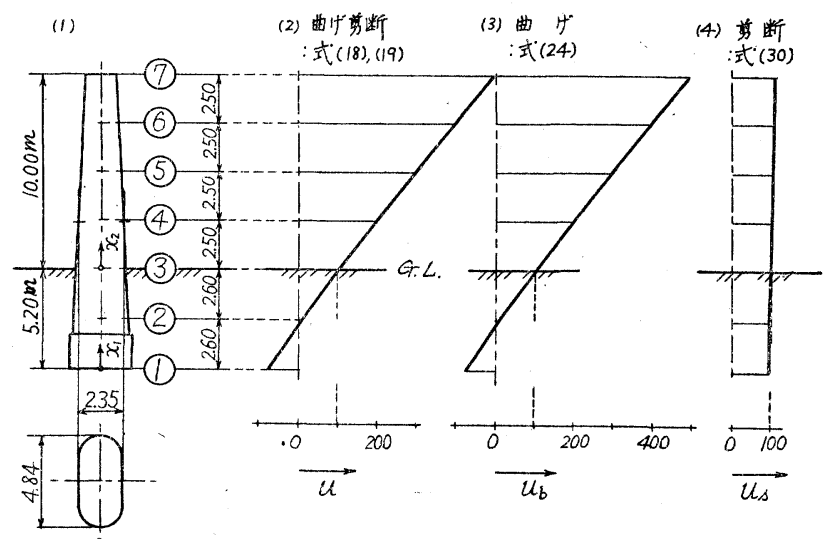


図一－正規函数形 $u$ の計算結果（九頭竜橋脚井筒）

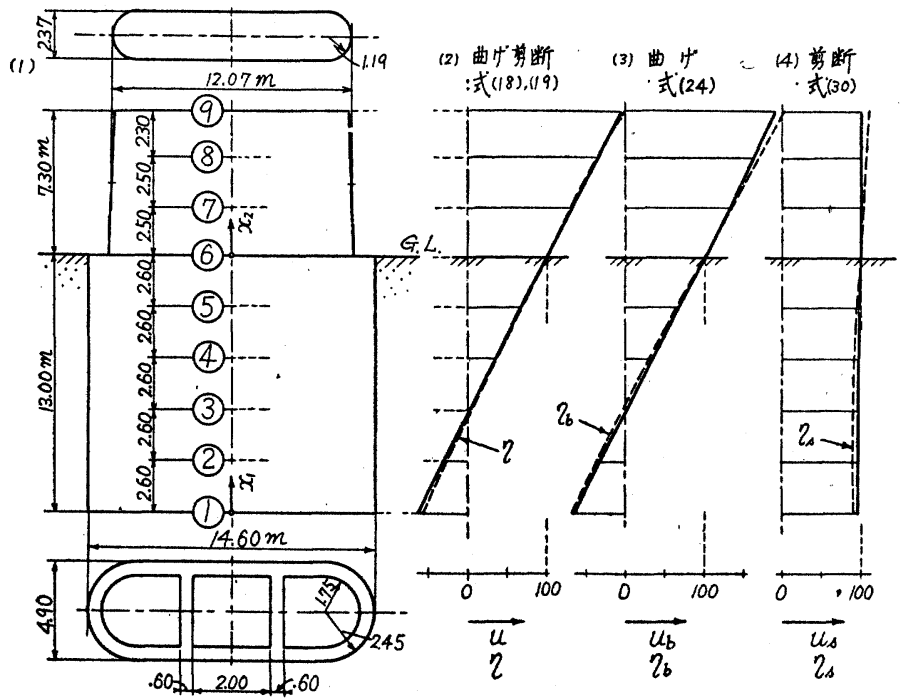

(11) 計算資料 a) 中角橋 No.5 橋脚: 橋軸飞平行方向: 図一3 (1). 根入部, 地上部共通江平均断面をと る。 $w_{1} a_{1}=w_{2} a_{2}=2.3 \times 10.20^{\circ} \mathrm{t} / \mathrm{m}, b_{1}=b_{2}=4.84 \mathrm{~m}, h, d=10.00,5.20 \mathrm{~m}, E_{1} I_{1}=E_{2} I_{2}=2.1 \times 10^{6} \times 4.19 \mathrm{t} / \mathrm{m}^{2}, G_{1}=$ $G_{2}=0.9 \times 10^{6} \mathrm{t} / \mathrm{m}^{2}, k_{1}{ }^{\prime}=k_{2}{ }^{\prime}=0.710, K_{0}=6000 \mathrm{t} / \mathrm{m}^{3}$ (振動実験よりの推定值 ${ }^{14}$ ) $), g=9.8 \mathrm{~m} / \mathrm{sec}^{2}$.

b) 九頭龍橋 7No.3 橋脚井筒 橋軸值角方向 : 図一4 (1)。 $w_{1} a_{1}, w_{2} a_{2}=2.4 \times 40.64,2.4 \times 27.33 \mathrm{t} / \mathrm{m}, b_{1}$, $b_{2}=4.90,2.37 \mathrm{~m}, h, d=7.30,13.00 \mathrm{~m}, E_{1} I_{1}, E_{2} I_{2}=2.1 \times 10^{6} \times 671.92,2.1 \times 10^{6} \times 306.04 \mathrm{t} / \mathrm{m}^{2}, K_{0}=5000 \mathrm{t} / \mathrm{m}^{3}$ (振動実験よりの推定值 $\left.{ }^{15}\right)$ ) $, G_{1}=G_{2}, g:$ a) と同値。

（2）固有周期 $T$ 上記両橋脚々対して式 (17) で曲げセン断, 式 (23) で曲げ, 式 (29) でセン断の各振動 数方程式を試算法によつて厳密に算出した固有周期 $T_{F}$ をとれぞれ表一1及び表一2に示した。な秥 Rayleigh 法による近似計算値 $T_{R}$, 純動摇周期 $T_{R}{ }^{\prime}$ を算出し，これら相互間の比率ないし精度を一括して同表上飞示した。

（3）正規函数形 $u （ 2 ）$ の計算で 厳密に決定した振動数 $n_{\mathrm{I}}$ を用いて式 (18)，(19）で曲げセン断，式 (24) で曲げ，式 (30) でセン断の各正規函数形を計算し，地盤面 B V括ける值を 100 として表一3及び表一4 亿一括表 示し，かつこれらの結果を図一3 及び図ー4 亿図示した。な招図一4 とは参考のため Rayleigh 法に採用した図

表一1 固有周期計算值 (中角橋脚)

\begin{tabular}{|c|c|c|c|c|c|c|c|c|}
\hline & \multicolumn{2}{|c|}{ 曲げ剪断 } & \multicolumn{2}{|c|}{ 曲 げ } & \multicolumn{2}{|c|}{ 剪断 } & \multicolumn{2}{|c|}{ 比率 $(\%)$} \\
\hline & & $T(\mathrm{sec})$ & & $T_{b}(\mathrm{sec})$ & & $T_{s}(\mathrm{sec})$ & $T_{b} / T$ & $T_{\Delta} / T$ \\
\hline & $\|(r)$ & 0.4585 & (23) & 0.4565 & & 1.001 & 99.56 & 1.83 \\
\hline Ragleigh 法 TR & (34) & 0.4604 & $(31)$ & 0.4540 & 33) & 0.0957 & 98.61 & 20.79 \\
\hline 精噔 下作 $(\%)$ & - & 100.41 & - & 99.45 & - & 95.60 & - & - \\
\hline
\end{tabular}

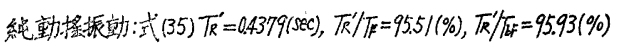

表一3 正規函数形計算值（中角橋脚）

\begin{tabular}{|c|c|c|c|c|c|c|c|}
\hline & \multirow{2}{*}{$\begin{array}{l}\text { 距漓 } \\
(m)\end{array}$} & \multirow{2}{*}{\multicolumn{2}{|c|}{ 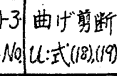 }} & \multirow{2}{*}{$\begin{array}{l}\text { 曲 ザ } \\
\text { Un: }\end{array}$} & \multirow{2}{*}{$\begin{array}{l}\text { 剪断 } \\
U_{s}: \text { 式(30) }\end{array}$} & \multicolumn{2}{|c|}{ 比 率 $(\%)$} \\
\hline & & & & & & $u_{b} / u$ & $u_{s} / u$ \\
\hline \multirow{5}{*}{$c_{2}$} & 10.00 & (7) & 492.44 & 489.12 & 107.71 & 99.33 & 21.87 \\
\hline & 7.50 & (6) & 392.39 & 389.67 & 107.19 & 99.31 & 27.32 \\
\hline & 5.00 & (5) & 292.73 & 290.62 & 105.76 & 99.28 & 36.13 \\
\hline & 2.50 & & 194.72 & 193.60 & 103.35 & 99.42 & 53.08 \\
\hline & $\frac{0}{5.20}$ & (3) & 100.00 & 100.00 & 100.00 & 100.00 & 100.00 \\
\hline \multirow{2}{*}{$x_{1}$} & 2.60 & (2) & 8.22 & 8.11 & 97.05 & 98.66 & 1180.66 \\
\hline & 0 & (1) & -79.65 & -79.76 & 96.07 & 100.14 & -120.62 \\
\hline
\end{tabular}

表一2 固有周期計算值（九頭竜橋脚井筒）

\begin{tabular}{|c|c|c|c|c|c|c|c|}
\hline & 曲げ剪断 & \multicolumn{2}{|c|}{ 曲 げ } & \multicolumn{2}{|c|}{ 剪 断 } & \multicolumn{2}{|c|}{ 此率 $(\%)$} \\
\hline & 式T $T$ (sec & I & $T_{b}(s e$ & I & $T_{s}(S S$ & $T_{b} / T$ & $T_{s} / T$ \\
\hline 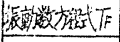 & (17) 0.2625 & 23 & 0.261 & 2 & 0.14 & 99.58 & 54.93 \\
\hline ayleigh法 $T_{R}$ & (34) $0.27 / 5$ & 3 & 0.260 & 3 & 0.122 & 96.02 & 45.19 \\
\hline 精度 $T_{R} / T_{F}(\%)$ & -103.42 & - & 99.7 & & 85.0 & $=$ & - \\
\hline
\end{tabular}

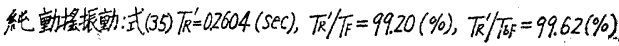
表一4 正規函数形計算值 (九頭竜橋脚井筒)

\begin{tabular}{|c|c|c|c|c|c|c|c|}
\hline \multirow[b]{2}{*}{ 慓 } & \multirow{2}{*}{\begin{tabular}{|l}
$\mid$ 距離 \\
$(m)$
\end{tabular}} & \multirow{2}{*}{ an-4 } & \multirow{2}{*}{$\begin{array}{l}\text { 曲计剪断 } \\
U: \text { 式(18),(19) }\end{array}$} & \multirow{2}{*}{ 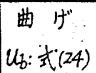 } & \multirow{2}{*}{$\begin{array}{c}\text { 尊断 } \\
u_{S}: \text { 式(30) }\end{array}$} & \multicolumn{2}{|c|}{ 比率 $(0 \%)$} \\
\hline & & & & & & $u_{b} / u$ & $u_{s} / u$ \\
\hline \multirow{3}{*}{$\dot{x}_{2}$} & 7.30 & & 195.51 & 193.96 & 101.52 & 99.21 & 51.69 \\
\hline & 5.00 & (8) & 165.53 & 164.32 & 101.37 & 99.27 & 61.24 \\
\hline & 2.50 & (7) & 132.80 & 133.14 & 100.85 & 100.26 & 75.94 \\
\hline & $\frac{0}{3.00}$ & (6) & 100.00 & 100.00 & 100.00 & 100.00 & 100.00 \\
\hline \multirow{5}{*}{$x_{1}$} & 10.40 & (5) & 66.28 & 66.71 & 99.02 & 100.65 & 149.40 \\
\hline & 7.80 & (4) & 33.15 & 33.52 & 98.27 & 101.12 & 296.44 \\
\hline & 520 & (3) & 0.36 & 0.44 & 97.73 & 122.22 & 549.25 \\
\hline & $2: 60$ & (2) & -32.38 & -32.63 & 97.40 & 100.77 & -300.80 \\
\hline & 0 & (1) & -65.34 & -65.67 & 97.30 & 100.51 & -148.91 \\
\hline
\end{tabular}


-2の仮定静曲線 $\eta$ を同じく地盤面を 100 として点 線で示した。

（4）基璴係数値 $K_{0}$ と周期 $T$ との関係 (2) か ら $T \cong T_{b}>T_{s}$, (3) から $u \cong u_{b} \neq u_{s}$ であるのでセ ン断效果は汪とんで認められない。ところが図一4(1) の地盤面 G. L. で完全固定すなわち $K_{0}=\infty$ とすると， セン断効果が非常に大きいととが考克られる。事実 $K_{0}=\infty$ 江対する周期の計算值は図一 5 中左下の表に示 したと特り $T>T_{s}>T_{b}$ である。したがつて同一寸法の 橋脚游いて $T_{b} \gtrless T_{s}$ 支支配するものはもつぱら $K_{0}$ の大きさであることがわかる。ととで $K_{0} 一 T, T_{b}, T_{s}$ の関係を計算したが，その一例を図一5儿示した。た だし表一1，2 で $T_{F}$ と $T_{R}$, 図一4で $u$ と とが 大差ないととから，図一5の結果はすべてクを用いた $T_{R}$ を算出したものである。しかし $T_{R}$ を計算するこ とはな新かりの手数を必要とするので， $T_{R}$ の代り に図一2の $\eta_{c}$ 安計算して図一5上飞 $K_{0}$ 亿対して図 示した。何となれば、 $\eta_{c}$ は橋脚井筒全体を頂部 C 換した場合のバネ常数の逆数を表わすので ${ }^{16)}, T$ 一 $K_{0}$ の代りに $\eta_{c}-K_{0}$ からセン断効果大小の概略を推察す ることができるからである。

\section{7. 計算結果とセン断効果とに関する考察}

(1) 計算結果 1) 固有周期 $T$ Vついて 表一1，2の $T_{F}$ は $5 \sim 7$ 回の試算でえた厳密值である。両表か ら $T>T_{b}>T_{s}$ かつ $T \cong T_{b}$ でセン断効果はいうまでもなく正である。 $T_{R}$ は曲げに対して $99.5 \%$, 曲げセン断 に対して 100〜103\% 程度の高精度を有するが，セン断では 85〜95\% となつている。これは図一2(2)の 斿を

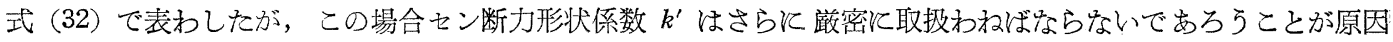
であると考兄られる ${ }^{17)}$ 。市た $T_{R}{ }^{\prime}$ が 95 99\% の高精度を有していることは岡体回転ないし変位が圧倒的で弾性 変形が少ないととを示している。な怙一般には $T_{R}<T_{F}$ であるが，曲げセン断に関してのみわづかではあるが， $T_{R}>T_{F}$ となつている原因浪いては明らかでない。

2) 正規函数 $u$ の形状飞ついて 図一3,4 から $u$ は直線に近くかつ

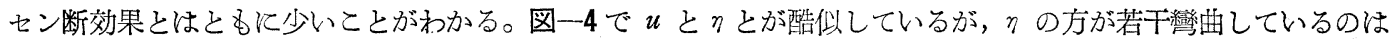
$\eta$ の仮定上当然である (図一2参照)。な和図一-3，4，表一3，4 から $u_{s}$ が $u$ 及び $u_{b}$ からかなりか子離れた形 状を示している点が注目される。

3） $T$ 亿及ぼす基礎係数值 $K_{0}$ の影響 図一5のうちでとの左上に示した点（b）は現地の振動実験から推定 した $T$ 及び $K_{0}$ の值を示す ${ }^{18)}$ 。すなわち実験值 $T$ は点直線 (a)一(b) 上，実験值 $K_{0}$ 沾直線 (b)一(c) 上

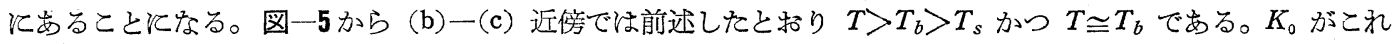
よりかなり大きい值となるとセン断効果が次等顕著現われ， $T_{b}=T_{s}$ となるのは汪 $K_{0}=50 \mathrm{~kg} / \mathrm{cm}^{3}$ 付近で ある。これらのことは近似的ではあるが， $\eta_{c}$ からも招よと推察できる。

（2）セン断效果 1) $T$ 汶対するセン断效果は $\left(T_{F} / T_{b F}\right)$-1で表わされるが，その值は 表一1，2 からそれ ぞれ $+0.44,+0.42 \%$ 飞すぎない。2） u 飞対しても同様で井筒底部 $\mathrm{A}$, 橋脚頂部 Cを代表的ととると, 表一 3,4 からそれどれ $\left(u_{A} / u_{A b}\right)-1=-0.14,-0.47 \%$ 及び $\left(u_{c} / u_{c b}\right)-1=+0.68,+0.80 \%$ でいずれる $1 \%$ 以下 である。3）ところが 1)，2）は $K_{0}=5$ 抢よび $6 \mathrm{~kg} / \mathrm{cm}^{3}$ と対する結果で， $K_{0}$ がこれより大きくなると図一5

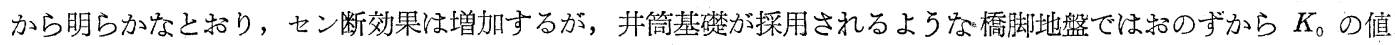
几一定の限界がある ${ }^{19}$ 。上記 1)，2)，3）からセン断効果は $1 \%$ 程度であつて，実際問題としてはこれを無視 してもさしつか党ないとらととが結論できる。

（3）本文飞物ける仮定との他の検討 1 ) 式 (9)，(21)，(26）で $\left(b_{1} K_{0}-w_{1} a_{1} n_{\mathrm{I}}^{2} / g\right)>0$ であることが弾性動 摇振動のいちじるしい特長であつて（）<0 は一般と弾性振動，（）=0 は根入部の及考虑した場合の純動摇振

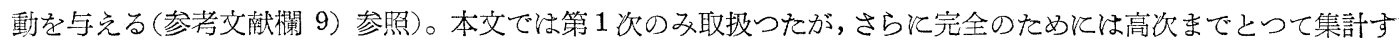




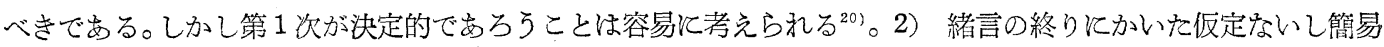

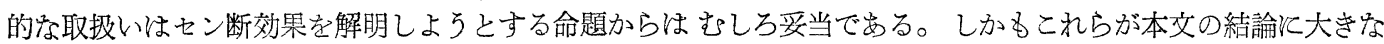
支障を及ぼすととほまず考えられない。3）剛体変位ないし回転吕圧倒的で弾性変形が少いという結果をえたが， これは橋脚井筒の岡忆対して地艋が柔であることが主原因であり，これがまた動摇振動が生じてセン断効果が小 さいといらととの大きな原因をなしているものと考光られる。しかしながらとのようにセン断効果は小さいとし

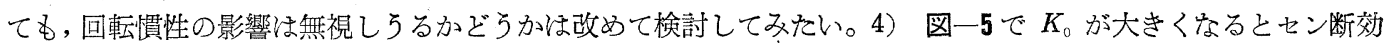
果堌加するが, $I_{1} / d ， I_{2} / h$ が大となつてす同一の傾向が考光られる。しかしてれらのことは定性的に考光られて も，橋脚井筒を対象とするかぎり実際上七ン断効果が定量的飞問題となるということはないと思われる。5）セン 断効果を判定する一近似法として図一5のと招り $T_{R}$ の代りに $\eta_{c}$ を用いたが，さらに簢単のためとは式(11)で $\sqrt{\beta_{1}} \gg \alpha_{1} / 2$, 式 (12) で $4 \beta_{2} \gg \alpha_{2}$ ならばセン断の影響は無規しても差支觉ないということがわかつた。

（4）本文の結論・橋脚井筒の振動飞関する限りその構造寸法飞振動方向と飞かかわらず，セン断効果は定量 的忙 $1 \%$ 程度であるので，実際上てれを無視しても差支觉ないというのが本文の結論である。この結果著者 がこれまで考究してきた曲げ振動的な取报いでよいということが䈯密な意味に招いて証明されたわけである。

終りに臨み終始御指導を仰いだ京大教授小西博士に対して深謝する次第である。

\section{参考交献その他}

1）後藤：橋脚井筒の耐震計算法住関する 2,3 の考察，土木学会第 11 回年次学術講演会（昭.30.5.29）で本 交の概要を講演。

2) 後藤：土木学会誌 38-4, 38-6, 39-7, 土木学会論文集 6, 24, その他

3）ティモシェンコ原著：工業振動学, pp 283-284, pp 286-287.

4) 戸部俊美: 回転慣性招よびせ九断力の影響を考虑せる均一断面はりの横振動飞ついて，日本機械学会諭文集 17-57, pp 14-19, 昭.26, 大野 豊: 線型かく乱力の作用するはりの振動飞ついて, 同上 17-57, pp 5-7. 戸部, 大野両氏は単飞 $\varphi=\partial y / \partial x, M=-E I \partial^{2} y / \partial x^{2}, S=\partial M / \partial x$ として, 境界条件飞セン断角を考㭸飞な いょうである。

5）酒井忠明：中空円筒殼体の強制振動飞よる忘力の一般解式及び実用解式，土木学会論文集 18, pp 62-63， 昭.28.9.

6）石崎潑雄: 剪断曲げ振動飞ついて, 日本建築学会研究報告 $22, \mathrm{pp} 47-48$, 昭.28.5, 同氏 : 地下室を有する 高層ビルの振動について, 同上 24, pp 189-190, 昭.28.10.

7）上掲 6) 第 2 論交の式（1）と著者の本交式（25）とを比較すると，基礎反力係数 $K_{0}$ を含む項の符号が逆 となつているが，著者の表示法が正しいととは容易汇証明できる。

8）後藤：橋脚井筒構造の動的耐震計算法飞ついて，土木学会論文集 24 , その第 1 節で言及。

9) $\left(b_{1} K_{0}-w_{1} a_{1} n^{2} / g\right)=0$ を満足する $n$ は $T=2 \pi V \overline{w_{1} a_{1} / g b_{1} K_{0}}$ を与える。との $T$ は図一1 の BC 及び $W$ が 全くない $\mathrm{AB}$ のみの純動摇周期である (上揭 8 ) 式 (2) と同一)。W, BC の載荷作用, $\mathrm{BC}$ の片持バリ作 用（ただし支持点はうごく）の結果上記の $T$ より大きくなるので当然（）>0である。実際飞本文 6.の 数值計算その他でる例外なく（）>0 であつた。

10）。式（9）は弾性基礎上飞あるハリが引張力をうけたときの式飞相当するので，その解はたと光ば K. Hayashi : Theorie des Trägers auf Elastischer Unterlage, 1921, S. 35, G1.(61), (64).

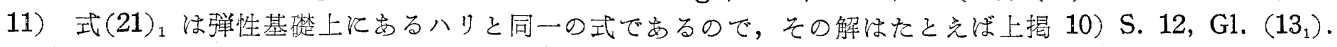

12) 後藤：土木学会論文集 6, pp 60-61, 式 (8)，(8) 1 及び pp 59-60 表-1.

13）後藤：土木学会誌 39-7, p. 17, 式（21）。ただし同式中 $d \alpha^{2} / 6[], h \alpha^{2} / 6[]$ とあるのはそれぞれ $d \alpha^{2}$ $/ 3[], h \alpha^{2} / 3[]$ と訂正する。

14）上掲 (2), p 66 .

15）当橋脚井筒のみが新設されからトラスが架設される直前に $(W=0)$, 起振 器 実施を行つたところ共振周期 $T_{r}=0.170 \mathrm{sec}$ を光た（昭.25.5.24）。ところが一方上揭 13）式（21）で底面反力の影響を式 (19）の $\beta$ で 表わし，これを考虑炕入れると $K_{0}=5 \mathrm{~kg} / \mathrm{cm}^{3}$ と詨して $T=0.178 \mathrm{sec}$ となつた。この事実から $K_{0}=5 \mathrm{~kg}$ $/ \mathrm{cm}^{3}$ は十分妥当な值でめるということが明言できる。

16) 後藤：土木学会誌 40-1. p 18, 式 (2) の下飞記入: $b_{2} / \eta_{c}{ }^{\prime}=b_{2} P / \eta_{e}=$ バネ常数 $k_{\circ}$

17）たと党代福田武雄, 構造力学 (昭.18), p 210, 式 (50.2)の $x$ 及び日本ポルトランドセメント同業会, コ

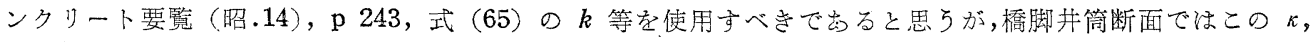
$k$ の算出が困難となりたので便宣上 $k^{\prime}$ をいた。

18）上揭 15） から $K_{0}=5 \mathrm{~kg} / \mathrm{cm}^{3}, T_{r}=0.170 \mathrm{sec}$ であるが，本計算では図一4（1）の井筒底面飞作用するかな り大きな上向反力無視したので $T=0.261 \mathrm{sec}$ が算出された。従つて本文の場合にはこの $0.261 \mathrm{sec}$ を実 験周期と考光てもさしつか党ないことになる。

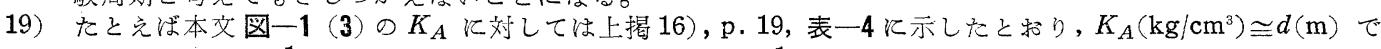
あり，かり $K_{0} \leqq \frac{1}{2} K_{A}$ と考光られるので, $K_{0}\left(\mathrm{~kg} / \mathrm{cm}^{3}\right) \leqq \frac{1}{2} d(\mathrm{~m}), d:$ 根入長，といら一定の限界があるこ とになる。

20）上揭 8) 図一 4 及び 表一5参照。

(昭. 30.4. 25) 